\title{
The Development of Learning Instrument Using Problem Based Learning Model to Improve Critical Thinking of Junior High School Students
}

\author{
Yusrina Santri Nasution ${ }^{1}$, Edi Syahputra ${ }^{2}$, Mulyono ${ }^{3}$ \\ ${ }^{1,2,3}$ Mathematics Education Department, Universitas Negeri Medan, Indonesia \\ yusrinasantri@gmail.com
}

\begin{abstract}
The study aims to: (1) determine the validity and effectiveness of learning instrumentswhich are developed, (2) determine the increase of critical thinking skills of student using learning instruments developed. This research is development research. The Development model used is 4-D model which consists of four stages: defining, designing, development and disseminate. The results of the defining phase are used to design a learning instrument, thenthis draft is validated and tested in the classto see its effectiveness. From this development, result obtained are: (1) The learning instrument developed is valid with an average validity total of lesson plan $=4.35$, student books $=4.35$, student worksheet = 4.36; (2) The learning instrumentis effective, that can be seen from both the individual and classical learning mastery are achieved, student activities within the specified tolerance limits and the student's response toward learning instruments are in good categories; (3) the increasing average of critical thinking skills of students from first trial test to second trial test is 0.20 points.
\end{abstract}

Keywords development of learning instrument; problem based learning model; critical thinking skills (MCA); mathematics software

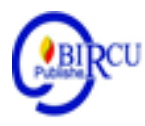

\section{Introduction}

One of the teacher's main tasks is teaching. To be able to teach mathematics, a teacher must be able to prepare lesson plans so mathematics lessonscan be received by students. The learning process will run well if the teacher can design a great learning process, starting from planning the learning tools, learning activities in class, to evaluating them. (Wahyudi, 2010) stated that the quality of education is determined by various dominant factors, such as teachers, the leadership of the principal, school facilities and infrastructure including the completeness of books, media/learning tools, school libraries, and curriculum that suits the needs of students.

The learning tools that needed in teaching and learning process namely are: syllabus, Lesson Plan (RPP), Student Worksheet (LKS), Evaluation Instrument or Learning Outcomes Test (THB), learning media, and student textbooks (Trianto, 2011). Thus, it can be seen that learning tools must be preparedand planned well before starting the learning process. These learning tools will facilitate students to actively involve in developing their potential into a competency. Therefore, teachers are obliged to provide learning experiences for students to carry out various activities that enable them to develop their potentials into competencies anddetermined it in a plan. But based on research (Effendi, 2008) regarding the planning of learning tools, teachers at the junior high schoolranked first in experienced more problems in it, as much as $40 \%$. Second, vocational schools as much as $25.3 \%$, third primary schools as much as $18.9 \%$, and fourth arehigh schools as much as $15.8 \%$. 


\section{Review of Literatures}

According to Effendi, more teachers in public schools $(16.3 \%)$ experienced problems compared to teachers in private schools $(11.8 \%)$. As for the factors causing/constraints in making lesson plans, namely: (1) Time, which includes these factor: the difficulty of the teacher in distributing time in the lesson plan andteacher has no time to make the lesson plan due to his/her busy schedule, and so on (41.05\%). Difficulties in describing the lesson material in lesson plan (14.74\%). Difficulties infollowing lesson plan standard format $(13.68 \%)$. Difficulties in finding the reference books $(13.68 \%)$, difficulties in determining used books, mandatory books and supporting books, difficulties in determining the teaching method $(8.42 \%)$. (Sugiantara, 2013) also found in his research that student's textbooks which are used as the most learning resource present formulas without providing opportunities for students to build their understanding of the material, and students have lack opportunities to interact and build their own understanding during the learning process.

From the explanations above, it can be concluded that if an activity planned well, the objective of the activity will be more directed and more successful. If the learning objective is to expect students to have certain competencies, then the lesson plan must be arranged in such a way to make sure the goal is achieved. The lesson plan is a series of events that will be delivered so that it can encourage student learning.

According to Regulation of Minister of Education and Culture of Republic of Indonesia (Permendikbud) number 103 of 2014 "Curriculum 2013 uses scientific-based learning approach". Some of the objectives of curriculum 2013 are to transform the learning student from being told to make student looking the answer, the assessment also transforms from result-oriented to process-orientedas well as balancing soft skills and hard skills.

Mathematical and critical thinking skills are two inseparable things, because mathematical is understood through critical thinking, and critical thinking is trained through learning mathematics (Lambertus, 2009). (Hassoubah, 2004) stated that critical thinking skills are important because critical thinking skills can support students in making correct decisions. With this ability, students can solve the problems systematically, formulate innovative questions and design solutions. In particular, critical thinking skills are needed in mathematics because learning mathematics will train students to think. (Santrock, 2012) suggested that according to Piaget, teenager's thinking ability is qualitatively same as an adult. Around ages 11 to 15, teenagers enter the formal operational stage; this stage is marked by a more logical, abstract, and idealistic way of thinking.

Whereas (Fachrurazi, 2011) stated that critical thinking in mathematics is used toexamine, verify, linked and evaluate all aspects that exist in a situation or a problem. (Johnson, 2009) said, "The purpose of critical thinking is to achieve deep understanding." However, in fact, student's critical thinking skills are still low. Besides, (Syahbana, 2012) only few schools teach the students with critical thinking skills. Most schools are likely encouraging their students to give correct answers rather than encourage them to come up with new ideas or rethink conclusions that already exist. So that it can be said that one of the causes of low critical thinking skills is the learning process at school.

The learning process will be effective if students are actively involved. One of the learning models that require active student participation in solving a problem is through problem-based learning model. The Problem Based Learning Model helps to enhance the development of learning skills in an open, reflective, critical, active mindset, and facilitates the success of problem solving, communication, group work, and creates better interpersonal 
skills than other models (Rusman, 2011). (Eggen, P \& Kauchak, 2012) mentioned that problem-based learning is a set of teaching models that use problems as a focus, thus it candevelop problem solving skills. (Arends, 2008) stated that the problem based learning model is a learning model in which students work on authentic problems to compile their own knowledge, developing higher level inquiry and thinking skills, as well as developing independence and self confidence.

Researchers are intending to use problem based learning models because of the situations and conditions found in the research subjects. Researchers apply problem-based learning models in developed learning tools because: 1) there will be more meaningful learning with this model, as students will apply their knowledge and skills to solve the problem; 2) students can combine their knowledge and skills, and apply them in a real context; 3) this model can improve critical thinking skills, foster student's initiative in work, have internal motivation to learn, and can develop interpersonal relationships in group work.

The research (Purwanti, 2017) regarding the development of problem based learning to improve problem-solving abilities and learning independence of students at High School 1 of South Kualuh. The results of his research concludes that: (1) the development of problembased learning instrument is valid with an average validator for lesson plan 4.60, student's books at 4.45 , teacher's books at 4.47 , student's worksheet at 4.52 , tests of ability to solve problems are moderately valid and valid, as well as learning independence is in the category of valid and moderately valid; (2) The use of learning tools to teach problem solving skills is in practical criteria; (3) The effectiveness of learning instrument meets the effective criteria; (4) The average improvement score in problem solving ability is increased from trial I to trial II with 0.29 points and classical mastery level increased by $15.12 \%$; (5) The average increase in student learning independence from trial I to trial II is 1.94 points.

Research (Simamora, 2014) with the title The Development of Learning Instrument and Authentic Assessment through Problem Based Learning Models to Improve Mathematical Communication Capabilities in the Equality and Linear Inequality of One Variable Subject in Class VII of SMP Negeri I Siantar.

The research shows that: (1) the level of student's mastery level obtained from the absorption skill is $85.57 \%$; (2) the level of communication skills mastery is $85.71 \%$; (3) the level of teacher's ability to manage learning is effective; (4) student'sactiveness is within the criteria of effectiveness of learning; (5) student responses to the learning component show positive responses.

Furthermore, research (Yulianti, 2010) has developed a mathematical learning instrument based on reciprocal teaching that can train student's critical thinking skills.

By applying this problem-based learning model, it is expected that students will get used to solve real problems, so that when there are problems intheir future work, students can solve their own problems by relying on their knowledge, experience and skills. For these reasons, it is necessary to develop quality learning tools, in accordance with the conditions and special characteristics of junior high school students.

\section{Research Methods}

Based on the problems mentioned above, the type of research is development research. Development Research is a research method used to produce a particular product, and test the effectiveness of the product. The development model used is a 4-D model developed by $\mathrm{S}$. Thiagarajan, Dorothy S. Semmel, and Melvyn I. Semmelthat consists of four stages: define, design, develop and disseminate. 9 Thiagarajan, et, al, 1974). 
This research was conducted in even semester year 2018/2019 in MTs Madinatussalam, Tembung, and Deli Serdang North Sumatra, Indonesia. The research sample was chosen randomly (random sampling). Two classes in MTs Madinatussalam, Tembung, Deli Serdang, North Sumatra were selected, namely class VIII-3 and VIII-2 with the number of students for class VIII- 3 are 34 students and class VIII- 2 are 22 students.

The procedure of the research performed in this study consists of 4 stages: The define stage consists of: a) the final preliminary analysis; b) analysis of learners; c) task analysis; d) conceptual analysis; and e) the formulation of learning objectives. The design phase consists of: a) book design; b) designing lesson plan; c) student worksheet design. In order to obtain valid criteria for the learning instrument, the instrument was validated by five validators that validate the contents of the instrument, then followed by validate the field or subject of the research to obtain valid and reliable questionnaires and questions.

The instruments used in this research are validation sheets and the effectiveness of learning instrument. The validation sheet consists of the instrument validation sheet and module validation sheet. The effectiveness of learning instrument consists of student learning mastery, student activities and student responses.

\section{Discussion}

In order to obtain valid criteria of the learning instrument, this research is validated by five validators who validate the contents of the instrument and the field to obtain valid and reliable questionnaires and questions.The average validation value of the Lesson Planis 4.39, the average total validation of Student Books is 4.35 , the average total student worksheet is 4.36. The total average for the whole values is at $4 \leq \mathrm{Va} \leq 5$ thus it can be categorized as valid. As for the critical thinking skills test, there are 4 questions met the valid criteria.

Effective criteriacan be seen in terms of the students learning mastery, student activities and student responses.

\subsection{Learning Mastery}

The results of critical thinking pretestcan are seen on trial I. The percentage of students that surpass the mastery level was $64.71 \%$, while the percentage of students who did not surpass the mastery level is at $35.29 \%$. As for the posttest result, it can be seen thatstudent surpass the mastery level with percentage $82.35 \%$, while the percentage of students who did not pass was $17.65 \%$. This percentage is obtained by dividing the number of students passed 28 , with the total students of class 34 , and multiplied by $100 \%$. However, this percentage hasn't met the classical learning mastery level which is $\geq 85 \%$. As a class is said to complete its study if class mastery percentage is $\geq 85 \%$. Therefore, it is necessary to revise the draft II and then try it back to the field. The data of student's critical thinking skills in the trial II showed that, the percentage of students who surpass the mastery levelin the pretest result was $68.75 \%$, while the percentage of students who did not pass is $31.25 \%$. As for the second posttest, there were $87.5 \%$ of students who surpassed it, and $12.50 \%$ of students did not surpass it. Thus, this percentage has met the set classical mastery level which is $\geq 85 \%$.

\subsection{Student Response}

Positive response toward the instrument is obtained when the number of students who give a positive response is greater than or equal to $80 \%$ from subjects studied on each trial (Sinaga, 2007). In trial I the total mean of student positive response students was 
$87.06 \%$, whereas in trial II the total meanof student positive response was $92.97 \%$ so this criterion had been achieved.

Table 1. Percentage of Student Responses in Trials I and II

\begin{tabular}{|l|l|c|c|}
\hline No. & \multicolumn{1}{|c|}{ Aspects } & $\begin{array}{c}\text { Trial I } \\
(\%)\end{array}$ & $\begin{array}{c}\text { Trial II } \\
(\%)\end{array}$ \\
\hline 1. & $\begin{array}{l}\text { Feel delighted in } \\
\text { learning component }\end{array}$ & 87.49 & 93.75 \\
\hline 2. & $\begin{array}{l}\text { The newness of } \\
\text { learning component }\end{array}$ & 84.56 & 92.97 \\
\hline 3. & $\begin{array}{l}\text { Interest for the next } \\
\text { lesson }\end{array}$ & 88.24 & 93.75 \\
\hline 4. & Language clarity & 83.82 & 90.63 \\
\hline 5. & $\begin{array}{l}\text { Interest in } \\
\text { appearance }\end{array}$ & 91.18 & 93.75 \\
\hline
\end{tabular}

From this table, it can be seen that the average percentages of student responses in both trials are above $80 \%$. Hence, this percentage has met the specified criteria. Overall, all aspects of student response have increased except for the third aspect, which is the interest for the next lesson.



Figure 1. Comparison of Student Response on Trials I and II

\subsection{Increased Critical Thinking Ability}

Data from the pretest and posttest of student'scritical thinking ability at the trial I were analyzed to determine the increase critical thinking skills of students. Based on the data in the critical thinking ability test in trial I, the summary of N-Gain results can be seen in the following table: 
Table 2. $N$-Gain Results for Critical Thinking Ability Test in Trial I

\begin{tabular}{|c|c|c|c|}
\hline Range & $\begin{array}{c}\text { Increase } \\
\text { Category }\end{array}$ & $\begin{array}{c}\text { Number } \\
\text { of } \\
\text { Students }\end{array}$ & $\begin{array}{c}\text { Percentage } \\
\%\end{array}$ \\
\hline $\mathrm{N}>0.7$ & High & 2 & 5.88 \\
\hline $\begin{array}{c}0,3<\mathrm{N} \leq \\
0.7\end{array}$ & Medium & 10 & 29.41 \\
\hline $\mathrm{N} \leq 0.3$ & Low & 22 & 64.71 \\
\hline \multicolumn{2}{|c|}{ Total } & 34 & 100 \\
\hline
\end{tabular}

Based on the table above, it can be seen that 2 students $(5.88 \%)$ increase their critical thinking ability in the "high" category. There are 10 students who increase their critical thinking ability in "Medium" category (29.41\%), and 22 students are categorized as "Low" at increasing their thinking ability (64.71\%). These results indicate that all students have increased critical thinking skills from the results of the pretest and posttest given.

At trial II, the increasing of critical thinking can be seen by count the gain value on pretest and posttest result, as seen in table below:

Table 3. $N$-Gain Results for Critical Thinking Ability Test in Trial II

\begin{tabular}{|c|c|c|c|}
\hline Range & $\begin{array}{c}\text { Increase } \\
\text { Category }\end{array}$ & $\begin{array}{c}\text { Number } \\
\text { of } \\
\text { Students }\end{array}$ & Percentage \% \\
\hline $\mathrm{N}>0.7$ & High & 6 & 18.75 \\
\hline $0,3<\mathrm{N} \leq 0.7$ & Medium & 15 & 46.87 \\
\hline $\mathrm{N} \leq 0.3$ & Low & 11 & 34.37 \\
\hline \multicolumn{2}{|r|}{ Total } & 32 & 100 \\
\hline
\end{tabular}

Based on the table above, it can be seen that 6 students (18.75\%) experiencedan increase in critical thinking skills in the "high" category 15 students experiencedan increase in critical thinking skills with "Medium" category (46.87\%), and 15 students experienced increase in critical thinking skills with the "Low" category $(34.37 \%)$.

\section{Conclusion}

The result of this research, the development of learning instruments using problem based models to improve critical thinking skills in junior high school student, has been already described in the result and discussion, it can be concluded that the function module of composition for students of grade of VIII has fulfilledthe valid criterion with average score of Lesson Plan is 4.39, average score of Student Books (BS) is 4.35, and average score for Student Worksheet (LKS) is 4.36. Learning instruments also meet the effective criteria as mastery learning achievement is $87.50 \%$, student activities also meet the ideal time tolerance criteria, and the average response of students in trial I is $87,006 \%$, while in trial II $92.97 \%$. So that the effective criteria have been reached.

With the development of PBL-based learning tools, it is hoped that students can be active in the learning process and improve students' critical thinking skills. 


\section{References}

Arends. (2008). "Belajar untuk Mengajar (Learning to Teach)". Yogyakarta: Pustaka Belajar.

Effendi. (2008). "Analisis Kualifikasi dan Kompetensi Profesi Guru serta Upaya Pengembangannya dalam Menyikapi UU Guru-Dosen",.

Eggen, P., and Kauchak, D. (2012). "Strategi dan Model Pembelajaran Mengajarkan Kontendan Keterampilan Berpikir. Jakarta: Indeks

Fachrurazi. (2011). "Penerapan Pembelajaran Berbasis Masalah untuk Meningkatkan Kemampuan Berpikir Kritis dan Komunikasi Matematis Siswa Sekolah Dasar". 1 (2): 76-89.

Hassoubah, Z.I. (2004). "Developing Creative \& Critical Thinking Skills". Bandung: Penerbit Nuansa.

Johnson, B. E. (2007). "CTL, Contextual Teaching and Learning: Menjadikan Kegiatan Belajar Mengajar Mengasyik kandan Bermakna". Bandung: Kaifa.

Kristyanawati, M. D., Suwandi, S., Rohmadi, M. 2019. Improvement of Exposition Text Writing Motivation and Skills Through the Application of the Problem Based Learning Model. Budapest International Research and Critics in Linguistics and Education (BirLE) Journal (2): 278-287.

Lambertus, (2009), "Pentingnya Melatih Keterampilan Berpikir Kritis dalam Pembelajaran Matematika di SD". Forum Kependidikan, 28 (2): 136-142

Lumbantobing, P. A. The Contribution of Lecturer Pedagogical Competence, Intellectual Intelligence and Self-Efficacy of Student Learning Motivation. Budapest International Research and Critics in Linguistics and Education (BirLE) Journal (3): 564-573.

Pohan, A. M., Asmin, and Menanti, A. 2020. The Effect of Problem Based Learning and Learning Motivation of Mathematical Problem Solving Skills of Class 5 Students at SDN 0407 Mondang. Budapest International Research and Critics in Linguistics and Education (BirLE) Journal (3): 531-539.

Purwanti, D, (2017) "Pengembangan Perangkat Pembelajaran Berorientasi Pembalajaran Berbasis Masalah untuk Meningkatkan Kemampuan Pemecahan Masalah dan Kemandirian Belajar Siswa SMA Negeri 1 Kualuh Selatan". Published Thesis. Medan: Postgraduate UNIMED.

Rusman. (2011). 'Model-Model Pembelajaran: Mengembangkan Peofesionalisme Guru. Jakarta: PT Raja Grafindo Persada.

Santrock, J. W. (2012). 'Perkembangan Masa Hidup", Jakarta: Erlangga.

Simamora, R. (2014). "Pengembangan Perangkat Pembelajaran dan Penilaian Otentik melalui Penerapan Model PBM untuk Meningkatkan Kemampuan Komunikasi Matematis pada Pokok Bahasan Persamaan dan Pertidaksamaan Linier Satu Variabel di Kelas VII SMP Negeri I Siantar". Medan: Postgraduate UNIMED.

Sinaga, B. (2007). "Pengembangan Model Pembelajaran Matematika Berdasarkan Masalah Berbasis Budaya Batak (PBMB3)". Disertession not published. Surabaya: PPs Unesa.

Sitompul, J. 2020. Student Perceptions of the Use of Android-Based Learning Media in the Production Ecrite Intermediaire Course. Budapest International Research and Critics in Linguistics and Education (BirLE) Journal (3): 616-624.

Sugiantara, A. (2013). "Pengembangan Perangkat Pembelajaran Matematika Realistik dengan Peta Konsep Pada Materi Trigonometri Di Kelas XI SMK". e-Journal Program Pascasarjana Universitas Pendidikan Ganesha Program Studi Matematika. 2: 1-11. 
Syahbana. (2012). "Pengembangan Perangkat Pembelajaran Berbasis Kontekstual untuk Mengukur Kemampuan Berpikir Kritis Matematis Siswa SMP”. Edumatica. 2 (2): 17 26.

Thiagarajan, S. et al, (1974.), 'Instructional Development for Training Teachers of Exceptional Children: A sourcebook". Indiana: Indiana University.

Trianto. (2011). "Mendesain Model Pembelajaran Inovatif-Progresif: Konsep, Landasan dan Implementasinya pada Kurikulum Tingkat Satuan Pendidikan (KTSP)”, Jakarta: Kencana.

Wahyudi. (2010). "Standar Kompetensi Profesional Guru", Jurnal Pendidikan Sosiologi dan Humaniora, 1 (2): 107-119.

Wulandari, U. N., Ansari, K., and Hadi, W. 2020. The Effect of Cooperative Learning Models and Learning Motivation towards the Skills of Reading Students in Public Elementary School 101883 Tanjung Morawa Sub-district. Budapest International Research and Critics in Linguistics and Education (BirLE) Journal (3): 1209-1219.

Yulianti. (2010). "Pengembangan Perangkat Pembelajaran Peluang Berbasis Reciprocal Teaching untuk Melatih Kemampuan Berpikir Kritis Siswa Kelas XI SMK Negeri 3 Lubuklinggau". Jurnal Pendidikan Matematika, 4 (2): 97-114.

Yusrizal, I., Hajar, and Tanjung, S. 2019. Analysis of Elementary School Teachers' Ability in Using ICT Media and its Impact on the Interest to Learn of Students in Banda Aceh. Budapest International Research and Critics in Linguistics and Education (BirLE) Journal (3): 37-49. 